\title{
Oxytocin and V1 vasopressin receptors in rabbit endometrium during pregnancy
}

\author{
M. Maggi, A. Peri, S. Giannini, G. Fantoni, V. Guardabasso* and M. Serio
}

Department of Clinical Physiopathology, Endocrinology Unit, University of Florence, Viale Morgagni 85, 50134 Florence, Italy; and *Istituto di Ricerche Farmacologiche Mario Negri, Consorzio Mario Negri Sud, 66030 S. Maria Imbaro, Italy

\begin{abstract}
Summary. Neurohypophysial hormone receptors were identified and characterized in rabbit endometrium and decidua by radioligand binding methods. The results strongly support the presence of a heterogeneity of sites in the decidua of parturient rabbits. The oxytocin site $\left(R_{1}\right)$ binds oxytocin and oxytocin analogues $\left(\left[\mathrm{Thr}^{4}\right.\right.$, Gly ${ }^{7}$ oxytocin and OTA) with high affinity, whereas the AVP site $\left(R_{2}\right)$ was selective for the V1 AVP analogues, $\left[\mathrm{Phe}^{2}, \mathrm{Orn}^{8}\right] \mathrm{VT}$ and $\mathrm{d}\left(\mathrm{CH}_{2}\right)_{5}$ TyrMeAVP. The concentration of oxytocin receptors was low (50-100 fmol/mg protein) at oestrus (Day 0) and on Day 29 of pregnancy, but increased significantly (about 8 -fold, $P<0.05$ ) during parturition. Conversely, V1 AVP receptors were more concentrated than the oxytocin sites at the end of pregnancy ( $150 \mathrm{fmol} / \mathrm{mg}$ protein) but did not change during parturition. These results indicate that neurohypophysial hormones have specific receptors not only in the myometrium but also in the uterine mucosa and we suggest that these receptors may participate in the regulation of uterine activity during pregnancy.
\end{abstract}

Keywords: oxytocin; vasopressin; endothelin; endometrium; rabbit; pregnancy; parturition

\section{Introduction}

Oxytocin is a neurohypophysial hormone that plays important roles in reproduction and lactation. Oxytocin acts on specific receptors present on myometrial and myoepithelial cells (Soloff et al., 1977) and stimulates contraction. The sensitivity of target tissues such as uterus or mammary gland to oxytocin changes during pregnancy or lactation. This has been related to specific modifications of the number of oxytocin receptors on the smooth muscle cells (Soloff et al., 1979). CaldeyroBarcia \& Posiero (1959) found an 8-fold increase in responsiveness of human uterus to oxytocin between the 20 th and 39 th week of pregnancy. A concomitant increase in myometrial oxytocin receptors, that parallels the increase in uterine spontaneous activity, was then demonstrated in pregnant women (Fuchs et al., 1982; Maggi et al., 1990) and rodents (Soloff et al., 1977; Fuchs et al., 1983; Riemer et al., 1986; Maggi et al., 1988b; Chan et al., 1990). These findings strongly indicate that oxytocin is involved in the initiation and maintenance of parturition. Vasopressin also induces uterine contraction, acting through V1 vasopressin receptors present in the myometrium of rabbits (Maggi et al., 1988b), rats (Chan et al., 1990) and humans (Maggi et al., 1990). However, in contrast to the oxytocin receptors, the concentration of V1 vasopressin receptors is only slightly affected by physiological events such as pregnancy and delivery. Therefore, the physiological significance of these sites in myometrium is still debated.

Oxytocin receptors have been also identified in the endometrium of several animal species (Roberts et al., 1976; Sheldrick \& Flint, 1985; Meyer et al., 1988; Soloff \& Fields, 1989), including humans (Fuchs et al., 1982, 1984), and have been characterized in the endometrium of the ewe (Ayad \& Wathes, 1989). Compelling evidence indicates that these sites are involved in the control of endometrial prostaglandin (PG) production (Roberts et al., 1976; Fuchs, 1987), via the 
hydrolysis of phosphoinositides (Flint et al., 1986). Conversely, no specific receptors for arginine vasopressin (AVP) have been demonstrated in the endometrium, although AVP as well as oxytocin stimulated inositol phosphate production in human decidua cells (Schrey et al., 1986). We have recently reported that endothelin- 1 is produced by endometrial cells of rabbits in primary culture and that this production is under control of neurohypophysial hormones (Orlando et al., 1990). Endothelin-1 is a potent vasoactive peptide (Yanagisawa et al., 1988) that also increases uterine activity, acting through specific receptors present in rabbit myometrium (Maggi et al., 1991).

The aim of this study was to investigate the presence of neurohypophysial hormone receptors in rabbit endometrium and decidua. These tissues were studied before (Day 0 ) and during pregnancy (Day 29) as well as during spontaneous delivery, in view of the primary role of neurohypophysial hormones at this time.

\section{Materials and Methods}

Animals. Sexually mature New Zealand White rabbits, weighing $3.5-4.5 \mathrm{~kg}$, at oestrus (purple and oedematous vulva) were obtained from a commercial breeder (Malenotti, Pratolino, Florence, Italy): 7 rabbits were mated with fertile bucks and killed after Day 29 of pregnancy $(\mathrm{N}=4)$ or during parturition $(\mathrm{N}=3)$ and 3 rabbits at oestrus were killed before mating (Day 0).

Chemicals. $\left[{ }^{3} \mathrm{H}\right] \mathrm{AVP}$ (sp. act. $70 \mathrm{Ci} / \mathrm{mmol}$ ) and $\left[{ }^{3} \mathrm{H}\right]$ oxytocin (sp. act. $36 \mathrm{Ci} / \mathrm{mmol}$ ) were purchased from New England Nuclear (Boston, MA, USA). The tritiated ligands were placed in aliquots in plastic tubes, sealed under nitrogen and frozen at $-80^{\circ} \mathrm{C}$. AVP, oxytocin and [1-( $\beta$-mercapto- $\beta, \beta$-cyclopentamethylenepropionic acid $) 2-(\mathrm{O}-$ methyl)Tyr, Arg $\left.^{8}\right]$ vasopressin, $\left(\mathrm{d}\left(\mathrm{CH}_{2}\right)_{5}\right.$ TyrMeAVP) (VI AVP antagonist; Kruszynski et al., 1980) were obtained from Sigma (St Louis, MO, USA). [Thr ${ }^{4}$, Gly ]oxytocin (oxytocin agonist; Lowbridge et al., 1977) [Phe ${ }^{2}$, Ile ${ }^{3}$, Orn $\left.{ }^{8}\right]$ vasopressin $\left(\left[\mathrm{Phe}^{2}, \mathrm{Orn}^{8}\right]\right.$ vasotocin) (V1 AVP agonist; Huguenin, 1966) and [1-( $\beta$-mercapto- $\beta, \beta$-cyclopentamethylenepropionic acid, 2-O-Me-Tyr ${ }^{3}, \mathrm{Orn}^{9}$, Tyr-amide)]vasotocin (OTA) (oxytocin antagonist; Elands et al., 1988) were obtained from Peninsula Laboratories Inc. (San Carlos, CA, USA).

Membrane preparations. Uterus and oviducts were promptly removed, dissected free of fat and adherent tissue, and plunged into ice-cold $0.9 \%(\mathrm{w} / \mathrm{v}) \mathrm{NaCl}$. Uterine horns were separated from oviduct and cervico-vaginal tract and opened longitudinally. The endometrium or decidua parietalis were separated from the underlining myometrium by scraping with the handle of the scalpel. Membranes were prepared as described previously (Maggi et al., 1986). The uterine mucosa was suspended in Buffer 1 (10 mM-Tris- $\mathrm{HCl}$, pH 7.4, containing $1.5 \mathrm{~mm}$-EDTA, 0.5 mM-dithiothreitol, $1 \mathrm{~mm}$-benzamidine, $0.01 \%$ bacitracin and $0.002 \%$ soybean inhibitor trypsin), homogenized with a glass-Teflon homogenizer (Thomas Scientific, Swedesboro, NJ, USA: 3 strokes at 1200 r.p.m.) and filtered through cheesecloth. The homogenate was centrifuged at $1000 \mathrm{~g}$ for $10 \mathrm{~min}$ at $4^{\circ} \mathrm{C}$. The supernatant containing the crude membrane fraction was then ultracentrifuged at $160000 \mathrm{~g}$ for $30 \mathrm{~min}$ at $4^{\circ} \mathrm{C}$.

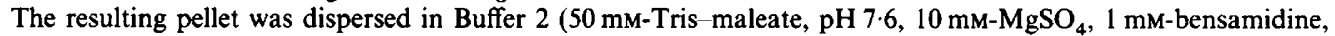
$0.01 \%$ bacitracin and $0.002 \%$ soybean trypsin inhibitor) and centrifuged again at $160000 \mathrm{~g}$ for $30 \mathrm{~min}$ at $4^{\circ} \mathrm{C}$. The final pellet was then resuspended in Buffer 2 and divided into small aliquants. The membrane preparation was frozen in solid $\mathrm{CO}_{2}$ and stored at $-80^{\circ} \mathrm{C}$ until assayed. Protein concentration was estimated using the Bio-Rad protein assay kit (Bio-Rad Laboratories, Munchen, West Germany) according to Bradford (1976).

Binding studies. Binding studies were conducted as previously described (Maggi et al., 1988b). Membrane samples $(0.3 \mathrm{mg} / \mathrm{ml})$ were incubated with ligands in Buffer 2 in the presence of $0.1 \% \mathrm{BSA}$ at $22^{\circ} \mathrm{C}$ for $2 \mathrm{~h}$ for tubes containing $\left[{ }^{3} \mathrm{H}\right] \mathrm{AVP}$ and for $5 \mathrm{~h}$ for tubes containing $\left[{ }^{3} \mathrm{H}\right]$ oxytocin.

$\left[{ }^{3} \mathrm{H}\right] \mathrm{AVP}$ and $\left[{ }^{3} \mathrm{H}\right]$ oxytocin were present at $1 \mathrm{nM}$ in tubes containing increasing concentrations $(0 \cdot 1-10000 \mathrm{nM})$ of unlabelled peptides and at $0 \cdot 1-1 \mathrm{nM}$ in tubes without unlabelled ligands. The reaction was terminated by rapid filtration through Whatman GF/B filters (Clifton, NJ, USA), presoaked for at least $3 \mathrm{~h}$ in ice-cold $50 \mathrm{~mm}$-Tris, pH 7.4, in $0.1 \% \mathrm{BSA}$, to minimize filter absorption. A semiautomatic cell-harvesting system (Brandel M-48R, Gaithersburg, $\mathrm{MD}, \mathrm{USA}$ ) was used. Filters were washed twice with $3 \mathrm{ml}$ ice-cold $50 \mathrm{~mm}$-Tris, $\mathrm{pH} 7.4$. Radioactivity retained by filters was measured in a liquid scintillation counter, after overnight incubation in $10 \mathrm{ml}$ scintillation fluid (Instagel, Packard Instruments Company Inc, Downers Grove, IL, USA). Self- and cross-displacement curves among $\left[{ }^{3} \mathrm{H}\right]$ oxytocin, $\left[{ }^{3} \mathrm{H}\right] \mathrm{AVP}$, and several analogues with different specificities for neurohypophysial hormone receptors were prepared, using decidual membranes from parturient rabbits. In additional studies receptor populations were investigated using a multiligand experimental design, in which multiple analogues (labelled ligand, unlabelled ligand, and blocking ligand) were present simultaneously in each assay tube (Maggi et al., 1988a, b).

Analysis of results. Families of self- and cross-displacement curves were analysed simultaneously using the program LIGAND (Munson \& Rodbard, 1980). Models of increasing complexity were evaluated (Maggi et al., 1988b). Selection among models was based on the root mean square error of each fit using an F-test based on the "extra-sumof-square principle" and on tests of randomness of the residuals around the fitted curves (Munson \& Rodbard, 1980). Statistical comparisons were performed using one-way analysis of variance (ANOVA) and Tukey's test with the SAS statistical package (SAS Institute Inc., Cary, NC, USA). 


\section{Results}

Mathematical modelling of the binding data strongly indicated the presence of a heterogeneity of sites in the decidua of parturient rabbits. The introduction of a second independent class of sites significantly improved the goodness of fit $(P<0.001)$. Figure 1 shows a typical family of self- and cross-displacement curves, while binding capacity and affinity constants are given in Table 1. Figure 2 provides a graphical summary of the relative selectivity of the different ligands for the two
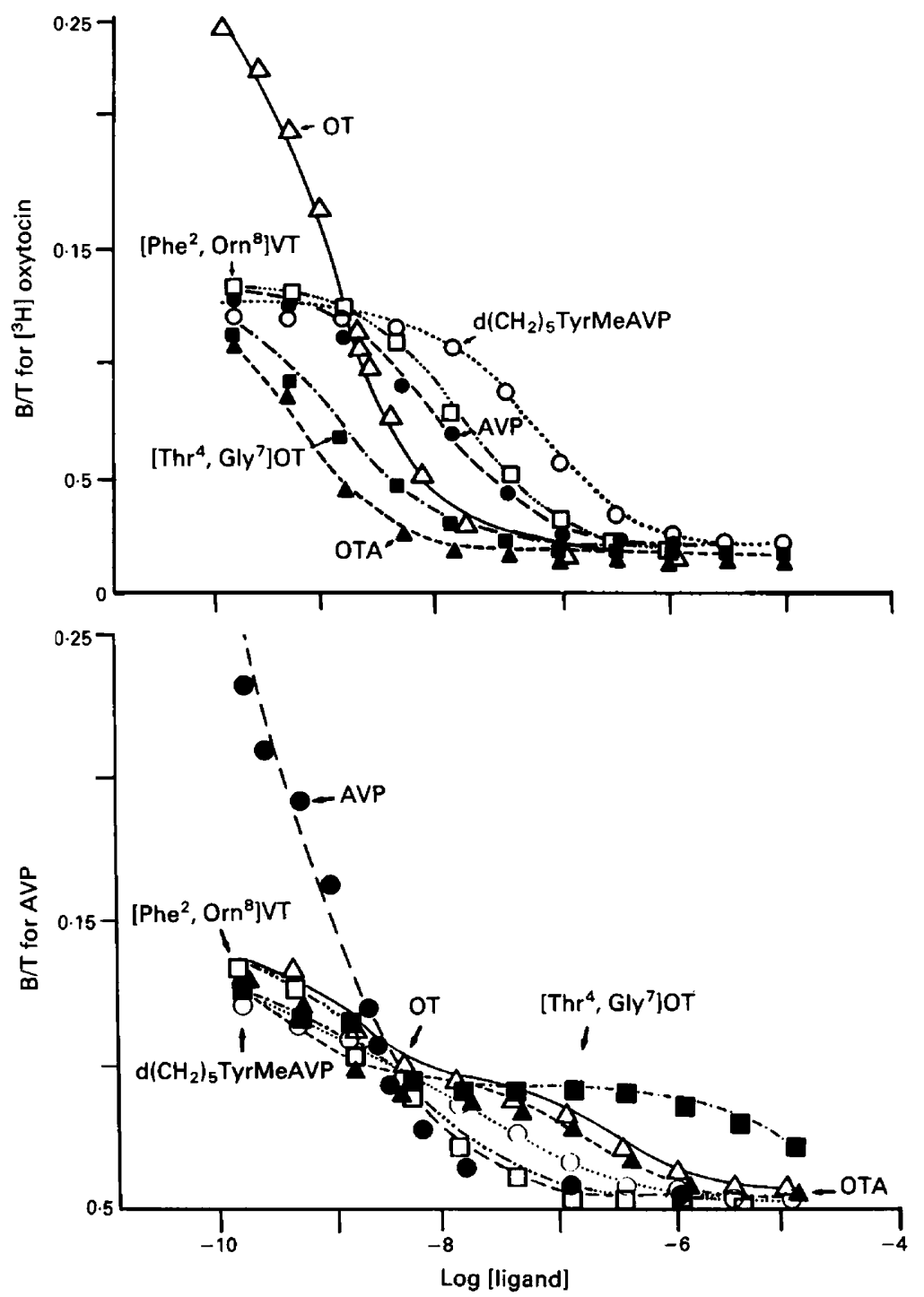

Fig. 1. Families of self- and cross-displacement curves between oxytocin $(\triangle), \operatorname{AVP}(\Theta),\left[\mathrm{Thr}^{4}\right.$, Gly ${ }^{7}$ ]oxytocin $(\square)$, OTA $(\Delta), \mathrm{d}\left(\mathrm{CH}_{2}\right)_{5}$ TyrMeAVP $(\mathrm{O})$ and $\left[\mathrm{Phe}^{2}\right.$, Orn $\left.{ }^{8}\right]$ vasotocin $(\square)$ obtained by the program LIGAND-PC (SCAGRF). In homologous competition curves, the concentrations of the tracers were progressively reduced to improve the characterization of the high affinity region of the binding curves. In the heterologous displacement curves, fixed (1 mM) concentrations of tracers were displaced by increasing concentrations of unlabelled ligands. 
Table 1. Concentration of receptors and affinity $\left(K_{d}\right)$ for oxytocin, AVP, OTA, d $\left(\mathrm{CH}_{2}\right)_{5}$ TyrMeAVP, $\left[\mathrm{Thr}^{4}, \mathrm{Gly}^{7}\right]$ oxytocin and $\left(\mathrm{Phe}^{2}, \mathrm{Orn}^{8}\right.$ ]vasotocin in decidua of parturient rabbits

\begin{tabular}{|c|c|c|}
\hline & \multicolumn{2}{|c|}{ Binding site } \\
\hline & $\mathrm{R}_{1}$ & $\mathrm{R}_{2}$ \\
\hline $\begin{array}{l}\text { Binding capacity } \\
\text { (fmol/mg protein) }\end{array}$ & $553 \pm 17$ & $61 \pm 6 \cdot 4$ \\
\hline \multicolumn{3}{|l|}{ Ligand $\left(K_{\mathrm{d}}, \mathrm{nM}\right)$} \\
\hline Oxytocin & $0.54 \pm 0.03$ & $30 \cdot 75 \pm 8$ \\
\hline AVP & $2.60 \pm 0.21$ & $0.14 \pm 0.02$ \\
\hline OTA & $0 \cdot 11 \pm 0 \cdot 01$ & $21.04 \pm 7.6$ \\
\hline $\mathrm{d}\left(\mathrm{CH}_{2}\right)_{5}$ TyrMeAVP & $20 \cdot 25 \pm 2 \cdot 22$ & $0.07 \pm 0.05$ \\
\hline$\left[\mathrm{Thr}^{4}\right.$, Gly $\left.^{7}\right]$ oxytocin & $0.34 \pm 0.04$ & $1043 \pm 438$ \\
\hline$\left[\mathrm{Phe}^{2}, \mathrm{Orn}^{8}\right]$ vasotocin & $5.48 \pm 0.6$ & $0.12 \pm 0.07$ \\
\hline
\end{tabular}

Binding parameters and standard errors were obtained from the simultaneous computer modelling of two families of self- and cross-displacement curves, using the program LIGAND (Munson \& Rodbard, 1980).

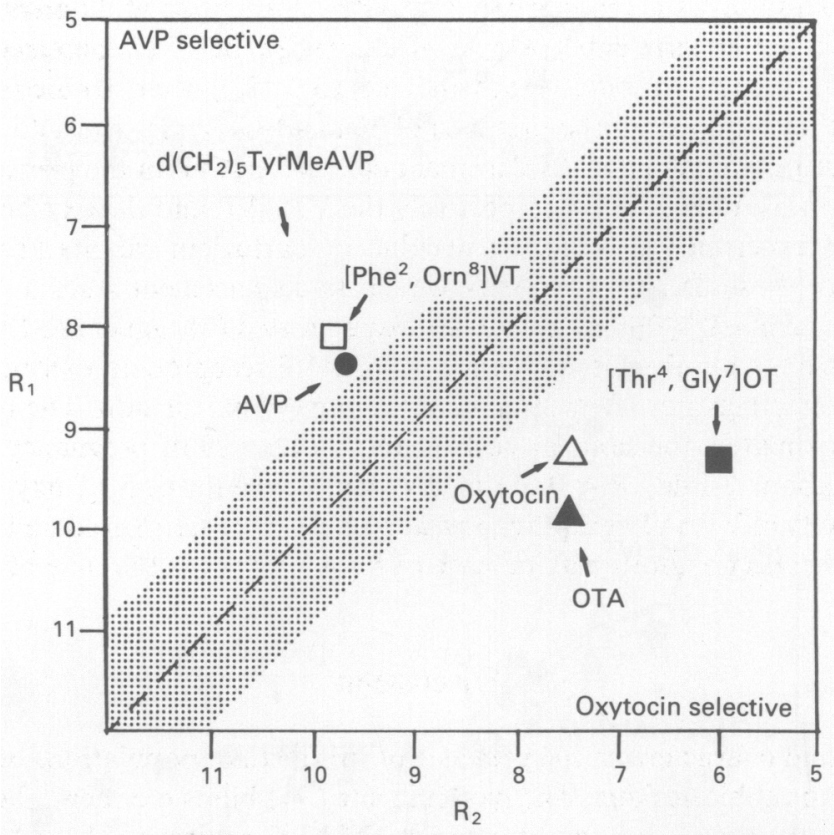

Fig. 2. Graphical representation of the affinity of oxytocin, AVP and several analogues for the oxytocin site $\left(\mathrm{R}_{1}\right)$ and the V1 AVP site $\left(\mathrm{R}_{2}\right)$ in the endometrium of parturient rabbits. The $K_{\mathrm{d}}$ values were obtained through the analysis of 16 curves from 2 membrane preparations in 2 competition experiments. Peptides in the region above the shaded area are selective for $\mathbf{R}_{2}$ (AVP site); peptides below the shaded area are selective for $\mathbf{R}_{1}$ (oxytocin site).

sites. AVP bound with high affinity to both sites $\left(R_{1}\right.$ and $\left.R_{2}\right)$, showing about 10 -fold selectivity for $\mathrm{R}_{2}$. The V1 agonist $\left[\mathrm{Phe}^{2}, \mathrm{Orn}^{8}\right]$ vasotocin and the V1 antagonist $\mathrm{d}\left(\mathrm{CH}_{2}\right)_{5}$ TyrMeAVP were the most selective ligands for $R_{2}$. Oxytocin preferentially bound, with about 100 -fold selectivity, to the 
Table 2. Concentration of receptors and affinity for oxytocin $\left(R_{1}\right)$ and V1 AVP $\left(R_{2}\right)$ in rabbit endometrium

\begin{tabular}{|c|c|c|c|c|}
\hline & \multicolumn{4}{|c|}{ Endometrium/decidua } \\
\hline & \multicolumn{2}{|c|}{ Oxytocin site } & \multicolumn{2}{|c|}{ AVP site } \\
\hline & $\begin{array}{l}\text { Binding capacity } \\
\text { (fmol/mg protein) }\end{array}$ & $\begin{array}{c}K_{\mathrm{d}} \\
(\mathrm{nM})\end{array}$ & $\begin{array}{l}\text { Binding capacity } \\
\text { (fmol/mg protein) }\end{array}$ & $\begin{array}{c}K_{\mathrm{d}} \\
(\mathrm{nM})\end{array}$ \\
\hline Day 0 & $90 \pm 75(3)$ & $0.33 \pm 0 \cdot 1$ & $18 \pm 1(3)$ & $0.41 \pm 0.38$ \\
\hline Day 29 & $66 \pm 7(4)$ & $0.24 \pm 0.07$ & $145^{* *} \pm 12(4)$ & $0.13 \pm 0.04$ \\
\hline Parturition & $544^{*} \pm 57(3)$ & $0.29 \pm 0.16$ & $102^{* *} \pm 16(3)$ & $0.19 \pm 0.1$ \\
\hline
\end{tabular}

Values (mean \pm s.e.m., no. of observations in parentheses) were derived from the analysis of multiligand experiments in rabbits: at estrous (Day 0), at the end of pregnancy (Day 29) and during spontaneous parturition. ${ }^{*} P<0.05$ compared with Day 0 or Day $29 .{ }^{* *} P<0.05$ compared with Day 0, using one-way ANOVA and Tukey's test.

$\mathrm{R}_{1}$ receptor. The oxytocin agonist [ $\mathrm{Thr}^{4}$, Gly ${ }^{7}$ ]oxytocin and the oxytocin antagonist OTA showed high selectivity for $R_{1}$. We therefore conclude that two distinct classes of sites are present in decidual membranes: $R_{1}$ that corresponds to the oxytocin site, and $R_{2}$ that corresponds to the V1 AVP site.

In attempting to establish the binding capacity of these receptors at different time of pregnancy, we performed 'blocking experiments' (Maggi et al., 1988a, b) in endometrial membranes from non-pregnant and pregnant rabbits. Oxytocin receptors $\left(\mathbf{R}_{1}\right)$ were studied using homologous competition curves for oxytocin in the presence of $10 \mathrm{nM}-\mathrm{d}\left(\mathrm{CH}_{2}\right)_{5}$ TyrMeAVP. V1 AVP receptors $\left(R_{2}\right)$ were studied using homologous displacement curves for AVP in the presence of $50 \mathrm{nM}-\left[\mathrm{Thr}^{4}\right.$, Gly ${ }^{7}$ ]oxytocin. This was done to mask respectively the V1 AVP and the oxytocin sites. The results obtained using this experimental design in decidua of parturient rabbits (Table 2) were absolutely consistent with those derived from self- and cross-displacement studies (Table 1). A similar validation of this experimental design was previously reported (Maggi et al., 1988b).

Table 2 illustrates the number of oxytocin and V1 AVP receptors in uterine mucosa at oestrus (Day 0), at the end of pregnancy (Day 29) and at the time of parturition. The binding capacity for oxytocin was approximately the same at oestrus and on Day 29 of pregnancy, but at parturition a dramatic surge (about 8 -fold, $P<0.05$ ) in decidual concentration of oxytocin receptors was observed. The capacity of V1 AVP receptors, low at oestrus, increased 8-fold on Day 29 of pregnancy $(P<0.05)$, but there was no additional increase of V1 AVP sites at the time of parturition.

\section{Discussion}

We have identified and characterized the presence of two distinct populations of neurohypophysial hormone receptors in rabbit decidua. The oxytocin site $\left(R_{1}\right)$ binds oxytocin, the selective oxytocin agonist $\left[\mathrm{Thr}^{4}\right.$, Gly $\left.{ }^{7}\right]$ oxytocin and the antagonist OTA. Conversely, the AVP site $\left(\mathrm{R}_{2}\right)$ shows selectivity for the V1 AVP agonist $\left[\mathrm{Phe}^{2}, \mathrm{Orn}^{8}\right]$ vasotocin and the V1 AVP antagonist d( $\left(\mathrm{CH}_{2}\right)_{5}$ TyrMeAVP. AVP binds with high affinity to both sites. These results are in perfect agreement with the ligand specificity of oxytocin and V1 vasopressin receptors present in the myometrium of rabbits (Maggi et al., 1988b). Furthermore, our study suggests that oxytocin and V1 vasopressin receptors serve distinct physiological functions. We found a sharp increase in the number of oxytocin receptors in the decidua of parturient rabbits, while V1 AVP sites were unchanged. These findings are in agreement with previous studies on oxytocin and AVP receptors in the myometrium of rodents (Maggi et al., 1988b; Chan et al., 1990) and humans (Maggi et al., 1990). In humans, a parallel rise in myometrial and decidual oxytocin receptors throughout pregnancy was reported 
(Fuchs et al., 1982, 1984). These results strongly suggest that the concentration of oxytocin receptors in the uterus plays a critical role during parturition. In rabbits sex steroids may represent one of the physiological signals for the surge in uterine oxytocin receptors at the end of pregnancy: (1) oxytocin receptors are very sensitive to the sex steroid milieu (Soloff, 1975; Soloff et al., 1983); (2) pharmacological treatments of immature rabbits with increasing concentrations of oestradiol$17 \beta$ stimulated a dose-dependent increase in myometrial oxytocin sites, while progesterone administration had the opposite effect (Maggi et al., 1988b); (3) an abrupt decline in the progesterone/ oestrogen ratio is present at the end of pregnancy (Challis et al., 1973).

The function of oxytocin and V1 AVP receptors in the endometrium and decidua is still unclear. Previous studies indicate that oxytocin modulates the endometrial production of prostaglandin (PG), while AVP is ineffective (see for review in Fuchs, 1987). It has been assumed that PGs are essential for the process of parturition, acting both on uterine contraction and cervical dilatation. Therefore, a dual role for oxytocin in parturition was proposed: eliciting myometrial contractions and releasing decidual PGs (Fuchs \& Fuchs, 1984). We recently proposed a new mechanism of action of oxytocin on endometrial cells (Orlando et al., 1990). We demonstrated that both oxytocin and V1 AVP receptors are involved in the regulation of endothelin secretion from rabbit endometrial cells in primary culture (Orlando et al., 1990). Indeed, the addition of [ $\left.\mathrm{Thr}^{4}, \mathrm{Gly}^{7}\right]$ oxytocin and $\left[\mathrm{Phe}^{2}, \mathrm{Orn}^{8}\right]$ vasotocin elicited an 8- and 2-fold increase, respectively, in endothelin-1 levels. This effect was completely counteracted by pretreatment with the antagonists OTA and $\mathrm{d}\left(\mathrm{CH}_{2}\right)_{5}$ TyrMeAVP. The relative selectivity of these analogues for the neurohypophysial hormone receptors in rabbit endometrium has been clearly shown in this study. Endothelin-1 is a potent uterotonic peptide, which stimulates uterine contractility (Kozuka et al., 1989; Maggi et al., 1991), acting through specific receptors present in myometrium (Maggi et al., 1991). An additional paracrine mediator of oxytocin activity is therefore proposed, i.e. endothelin-1 (Orlando et al., 1990; Maggi et al., 1991). However, the real contribution of this peptide in the initiation of parturition has yet to be assessed.

In conclusion, we have demonstrated that at the time of spontaneous parturition oxytocin, but not AVP receptors increase in the uterine mucosa as well as in the muscular layer. The activation of these receptors by endogenous (maternal or fetal) oxytocin may promote delivery of the fetus directly (contraction of myometrium) or through the stimulation of endometrial prostaglandins or endothelin secretion.

The work was financially supported by a grant from the University of Florence and by a grant from the Consiglio Nazionale delle Ricerche (CNR). The work of M.M. was supported by a special grant from FIDIA Pharmaceuticals, Abano Terme, Italy.

\section{References}

Ayad, V.J. \& Wathes D.C. (1989) Characterization of endometrial and myometrial oxytocin receptors in the non-pregnant ewe. J. Endocr. 123, 11-18.

Bradford, M.M. (1976) A rapid and sensitive method for quantitation of microgram quantities of protein, utilizing the principle of protein-dye binding. Analyt. Biochem. 72, 248-254.

Caldeyro-Barcia, R. \& Poseiro, J.J. (1959) Oxytocin and the contractility of the human uterus. Ann. N.Y. Acad. Sci. 75, 813-830.

Challis, J.R.G., Davies, I.J. \& Ryan, K.J. (1973) The concentration of progesterone, estrone and 17- $\beta$ estradiol in the plasma of pregnant rabbits. Endocrinology 93, 971-976.

Chan, W.Y., Hill, P.S. \& Hruby, V.J. (1990) Oxytocinand vasopressin-binding sites in the rat uterus: competition binding and inhibitory $\mathrm{pA}_{2}$ studies with oxytocin and oxytocin antagonists. Endocrinology 126, 2095-2101

Elands, J., Barberis, C., Jard, S., Tribollet, E., Dreifuss, J., Bankowski, K., Manning, M. \& Sawyer, W.H. (1988) ${ }^{125}$ I-labelled d $\left(\mathrm{CH}_{2}\right)_{5}\left[\mathrm{Tyr}(\mathrm{Me})^{2}, \mathrm{Thr}^{4}\right.$, Tyr$\mathrm{NH}_{2}{ }^{9}$ ]OVT: a selective oxytocin receptor ligand. Eur. J. Pharm. 147, 197-207.

Flint, A.P.F., Leat, W.M.F., Sheldrick, E.L. \& Stewart, H.J. (1986) Stimulation of phosphoinositide hydrolysis by oxytocin and the mechanism by which oxytocin controls prostaglandin synthesis in the ovine endometrium. Biochem. J. 237, 797-805.

Fuchs, A.R. (1987) Prostaglandin $F_{2 a}$ and oxytocin interactions in ovarian and uterine function. J. Steroid Biochem. 27, 1073-1080. 
Fuchs, A.R. \& Fuchs, F. (1984) Endocrinology of human parturition: a review. Br. J. Obstet. Gynaecol. 91, 948-967.

Fuchs, A.R., Fuchs, F., Husslein, P., Soloff, M.S. \& Fernstrom, M.J. (1982) Oxytocin receptors and human parturition: a dual role for oxytocin in the initiation of labor. Science, $N Y$ 215, 1396-1398.

Fuchs, A.R., Peryasamy, S., Alexandrova, M. \& Soloff, M.S. (1983) Correlation between oxytocin receptor concentration and responsiveness to oxytocin in pregnant rat myometrium: effect of ovarian steroids. Endocrinology 113, 742-749.

Fuchs, A.R., Fuchs, F., Husslein, P. \& Solofi, M.S. (1984) Oxytocin receptors in human uterus during pregnancy and parturition. Am. J. Obstet. Gynecol. 150, 734-741.

Huguenin, R.L. (1966) Synthese de la desamino-1-Orn8-vasopressine, de la desamino-1-Phe-2-Orn-8-vasopressine, de la desamino-1-Ile-3-Orn-8-vasopressine (= desamino-1-Orn-8-oxytocine) et de la desamino-1Phe-2-Ile-3-Orn-8-vasopressine (=desamino-1-Phe2-Orn-8-oxytocine). Helv. Chim. Acta 49, 711-725.

Kozuka, M., Ito, T., Hirose, S., Takahashi, K. \& Hagiwara, H. (1989) Endothelin induces two types of contractions of rat uterus: phasic contractions by way of voltage-dependent calcium channels and developing contractions through a second type of calcium channels. Biochem. Biophys. Res. Commun. 159 , 317-323.

Kruszynski, M., Lammek, B., Manning, M., Seto, J., Haldar, J., Sawyer, W.H. (1980) [1-( $\beta$-mercapto- $\beta, \beta-$ cyclopentamethylenepropionic acid), 2-(O-methyl)tyrosine $]$ arginine vasopressin and $[1-(\beta$-mercapto- $\beta$, $\beta$-cyclopentamethylenepropionic acid)]arginine vasopressin, two highly potent antagonists of the vasopressor response to arginine vasopressin. J. med. Chem. 23, 364-368.

Lowbridge, J., Manning, M. (1977) Synthesis and some pharmacological properties of [4-Threonine, 7-Glycine]oxytocin, [1-(1-2-hydroxy-3-mercaptopropanoic acid),4-threonine,7-glycine]oxytocin (hydroxy[Thr ${ }^{4}$, Gly ${ }^{7}$ ]oxytocin, and [7-glycine]oxytocin, peptides with high oxytocic-antidiuretic selectivity. $J$. med. Chem. 20, $120-123$.

Maggi, M., Kassis, S., Malozowski, S., Guardabasso, V. \& Rodbard, D. (1986) Identification and characterization of a vasopressin isoreceptor in porcine seminal vesicles. Proc. natn. Acad. Sci. USA 83, 8824-8828.

Maggi, M., De Rossi, M., Amenta, F., Genazzani, A.D., Rodbard, D. \& Serio, M.(1988a) Similarity of vasopressin receptors in seminal vesicles and renal medulla of pigs. J. Reprod. Fert. 84, 401-407.

Maggi, M., Genazzani, A.D., Giannini, S., Torrisi, C., Baldi, E., Di Tommaso, M.R., Munson, P.J., Rodbard, D. \& Serio, M. (1988b) Vasopressin and oxytocin receptors in vagina, myometrium and oviduct of rabbits. Endocrinology 122, 2970-2980.

Maggi, M., Del Carlo, P., Fantoni, G., Giannini, S., Torrisi, C., Casparis, D., Massi, G.B. \& Serio, M. (1990) Human myometrium during pregnancy contains and responds to $\mathrm{V} 1$ vasopressin receptors as well as oxytocin receptors. J. clin. Endocr. Metab. 70, $1142-1154$.
Maggi, M., Vannelli, G.B., Peri, A., Brandi, M.L., Fantoni, G., Giannini, S., Torrisi, C., Guardabasso, V., Barni, T., Toscano, V., Massi, G.B. \& Serio, M. (1991) Immunolocalization, binding and biological activity of endothelin in rabbit uterus: effect of ovarian steroids. Am. J. Physiol. 270, 292-305.

Meyer, H.H.D., Mittermeier, T. \& Schams, D. (1988) Dynamics of oxytocin, estrogen and progestin receptors in the bovine endometrium during the estrous cycle. Acta endocr., Copenh. 118, 96-104.

Munson, P.J. \& Rodbard, D. (1980) LIGAND: a versatile computerized approach for characterization of ligand-binding systems. Analyt. Biochem. 107, 220239.

Orlando, C., Brandi, M.L., Peri, A., Giannini, S., Fantoni, G., Calabresi, E., Serio, M. \& Maggi, M. (1990) Neurohypophyseal hormone regulation of endothelin secretion from rabbit endometrial cells in primary culture. Endocrinology 126, 1780-1782.

Riemer, K.R., Goldfien, A.C., Goldfien, A. \& Roberts, J.M. (1986) Rabbit uterine oxytocin receptors and in vitro contractile response: abrupt changes at term and the role of eicosanoids. Endocrinology 119 , 699-709.

Roberts, J.S., McCracken, J.A., Gavagan, J.E. \& Solofi, M.S. (1976) Oxytocin-stimulated release of prostaglandin $\mathrm{F}_{2 a}$ from ovine endometrium in vitro: correlation with estrous cycle and oxytocin-receptors binding. Endocrinology 99, 1107-1114.

Schrey, M.P., Read, A.M. \& Steer, P.J. (1986) Oxytocin and vasopressin stimulate inositol phosphate production in human gestational myometrium and decidua cells. Bioscience Rep. 6, 613-619.

Sheldrick, E.L. \& Flint, A.P.F. (1985) Endocrine control of uterine oxytocin receptors in the ewe. J. Endocr. 106, 249-258.

Solofi, M.S. (1975) Uterine receptors for oxytocin: effects of estrogens. Biochem. Biophys. Res. Commun. 65, 205-212.

Soloff, M.S. \& Fields, M.J. (1989) Changes in uterine oxytocin receptor concentrations throughout the estrous cycle of the cow. Biol. Reprod. 40, 283-287.

Solofi, M.S., Schroeder, B.T., Chakraborty, J. \& Pearlmutter, A.F. (1977) Characterization of oxytocin receptors in the uterus and mammary gland. Fedn Proc. Fedn Am. Socs exp. Biol. 36, 1861-1866.

Soloff, M.S., Alexandrova, M. \& Fernstrom, M.J. (1979) Oxytocin receptors: triggers for parturition and lactation? Science, NY 204, 1313-1315.

Soloff, M.S., Fernstrom, M.A., Peryasamy, S., Soloff, S., Baldwin, S. \& Wieder, M. (1983) Regulation of oxytocin receptor concentration in rat uterine explants by estrogens and progesterone. Can.J. Biochem. Cell Biol. 61, 625-630.

Yanagisawa, M., Kurihara, H., Kimura, S., Tomobe, Y., Kobayashi, M., Mitsui, Y., Yazaki, Y., Goto, K. \& Masaki, T. (1988) A novel potent vasoconstrictor peptide produced by vascular endothelial cells. Nature, Lond. 332, 411-415.

Received 22 June 1990 